\title{
Indonesian - English Code-Mixing in Novel Touché by Windhy Puspitadewi
}

\author{
Zawranisa Meigasuri*, Putu Lirishati Soethama \\ English Department, Faculty of Arts, Udayana University \\ [zawranisa.mei@gmail.com], [lirishatinya@yahoo.com] \\ Denpasar, Bali, Indonesia \\ *Corresponding Author
}

\begin{abstract}
This study aims to find out the types of code-mixing, to identify word class categories of the words being mixed, and to explain the factors of using mixed languages in Touché novel. Data were taken from Touché novel by Windhy Puspitadewi and were collected by using documentation method. The sample data were selected by using purposive sampling method. This study used qualitative method to analyze the data and the results are presented in formal and informal method. In order to analyze the code-mixing, the theory of factors in using codemixing proposed by Tej K. Bhatia and William C. Ritchie (2013) was used. The result showed that from 85 Indonesian - English code-mixing data that had been collected, it was found that 39 data are insertion code-mixing, 36 data are alternation code-mixing and 10 data are congruent lexicalization. The categories of words being mixed are varied such as words (i.e. nouns, adjectives, etc.), phrases (i.e. noun phrases, adverb phrases, etc.), and clauses (i.e. dependent and independent clauses). There are four factors found in using code-mixing in the novel: social roles and relationships of participants, situational factors, message-intrinsic factors, and language attitudes, dominance and security.
\end{abstract}

Keywords: Sociolinguistics, code-mixing, novel

\begin{abstract}
Abstrak
Penelitian ini bertujuan untuk menemukan tipe-tipe campur kode, mengidentifikasi kelas kata dari kata-kata yang dicampur, dan menjelaskan faktor yang mempengaruhi penggunaan bahasa campuran pada novel Touché. Data untuk penelitian ini diambil dari novel Touché karya Windhy Puspitadewi menggunakan metode dokumentasi. Sampel data dipilih dengan menggunakan metode pengambilan sampel bersyarat. Penelitian ini menggunakan metode kualitatif untuk menganalisa data dan hasil penelitian disajikan menggunakan metode formal dan informal. Untuk menganalisa pencampuran kode, teori faktor penggunaan campur kode yang dikemukakan oleh Tej K. Bhatia dan William C. Ritchie (2013) digunakan. Hasil analisis menunjukkan bahwa dari 85 campur kode Bahasa Indonesia dan Inggris yang telah dikumpulkan, ditemukan 39 data tergolong campur kode sisipan (insertion), 36 data adalah campur kode bergantian (alternation), dan 10 data merupakan leksikalisasi sebangun (congruent lexicalization). Kategori kelas kata dari kata-kata yang dicampur bervariasi seperti kata (yaitu kata benda, kata sifat, dll), frasa (yaitu frasa nomina, frasa keterangan, dll), dan klausa (klausa utama dan pembantu). Ada empat faktor yang mempengaruhi penggunaan campur kode di
\end{abstract}


dalam novel yaitu peran sosial dan hubungan para partisipan, faktor situasional, faktor makna intrinsik, dan sikap bahasa, dominasi dan keamanan.

Kata kunci: Sosiolinguistik, Campur kode, Novel

\section{INTRODUCTION}

Language used in society is very diverse and depends on many aspects. The field that studies the connection between language and society is called sociolinguistics. Sociolinguistics has become a popular field of study that concerns with language and human social system, such as the way language is used in different social context, how the language works and its social relation (Holmes, 2013). Sociolinguistics investigates language and society that often involving many aspects such as sex, age, social class, educational background of the speaker. Besides, sociolinguistics also cope the phenomenon of people that acquire two or more languages. In one speech community, each individuals may be bilingual. This causes people switch and mix the languages depend on the situation and the people whom they are interacting with. This phenomenon is called code-switching and code-mixing. Wardhaugh (2006) states code-switching (also called code-mixing) is languages that can occur in conversation between speakers' turns or within a single speaker's turn.

Phenomenon of code-switching and code-mixing has become an interesting topic to be discussed, especially because it reflects the language use related to globalization era in real life thesedays. English plays an important role as international language in the world and people are expected to comprehend the language. It helps people from dissimilar background to communicate. Due to more than one language skill that a person could have, often people are not aware that they mixed the languages. Hence, the mixing occurs in spoken and written form, such as daily conversation, teaching, television program, social media, magazine, advertisement, as well as in literary work namely novel.

This study discuses the use of two languages: Indonesian and English that are found in Indonesian novel as written form of code-mixing. Many studies have raised the issue of code-mixing purposes in literature. As Keller and Keller (1993) said those are as identity marking, alienation, characterization and style. In a more recent work, Torres (2007) also added that it represents a reality of segments of the population that are living between cultures and languages as literary language actualizes bilingual or bicultural communities. The impact of inserting code-mixing in a novel may also vary such as indirectly affects readers' language style. As the use of code-mixing is frequently shown in Touché novel by Windhy Puspitadewi. The novel is targeting teenage readers which impact the readers using mixed up codes. Furthermore, finding out the types of code-mixing that the author use and the factors of using code-mixing through the characters' utterances are also interesting to be analyzed.

There are some journals related to this study. Those journals will be explained below: The first journal to be reviewed was written by Mujiono, Rahayu Wilujeng, and Muhammad Suharto (2017) entitled Code Mixing as a Communication Strategy Performed by Outbound Call (OBC) Center Agents. The journal aims to analyze types and reasons that influence the used of code mixing in OBC Center Agents which has implemented in their call center activities. This journal used theory of 
code-mixing types by Musyken (2001) and Wardhaugh (2006), theory of codemixing reasons are by Bhatia and Ritchie (2004), Holmes (2013) and Gumperz (1982).

The second journal to be reviewed is entitled Code-Mixing of English in the Entertainment News of Chinese Newspaper in Malaysia by Lau Su Kia, Xiongyong Cheng, Tan Kooi Yee, and Choo Wee Ling (2011). This study sought to analyze the code-mixing in entertainment news of Malaysian Chinese newspaper.

The third journal that was reviewed is entitled An Analysis of Code Switching and Code Mixing as Found in Television Advertisement. It was written by Mei Lyna Girsang (2015). This journal discussed about types of Code Switching and Code Mixing in ANTV television advertisement, the most dominant type of Code Switching and Code Mixing and the reasons of using Code Switching and Code Mixing. This journal used theory proposed by Hoffman (1991).

The forth journal to be reviewed was written by Fithrah Auliya Ansar (2017) entitled Code Switching and Code Mixing in Teaching-Learning Process. The journal aims to analyze types, reasons and functions in switching and mixing languages which has implemented in teaching-learning process in Indonesia. This journal used theory by Crystal (1987) and Eldridge (1996).

The fifth journal was written by Enggar Mulyajati (2017) entitled The Indonesian-English Code-Mixing in Just Alvin Show at Metro TV. The journal discusses about the types of code-mixing and the syntactic units that mixed in speeches of Just Alvin Show Metro TV. The theory types of code-mixing proposed by Muysken (2000) was used.

\section{METHOD}

The research method in this study comprises many aspects such as data source, method and technique of collecting data, method and technique of analyzing data, and method and technique of presenting data analysis.

\section{Data Source}

Data were taken from a novel entitled Touché written by Windhy Puspitadewi. The novel was published in May $5^{\text {th }} 2011$ by Gramedia Pustaka Utama. The novel has 208 pages. This novel was chosen because it has an interesting story, not merely about teen romance but also fantasy, friendship, adventure and family. This novel categorizes as teen literature and is one of best-selling Indonesian novel according to Goodreads, the largest website for readers and book recommendations in the world, with 2.374 ratings and 192 reviews. Some part of the dialogue are mixing Indonesian and English language in order to support characterization of the characters created by the author.

\section{Method and Technique of Collecting Data}

The data were collected by using documentation method which done in several steps. First, reading the whole novel intensively. Second, the dialogue that contain Indonesian - English codemixing were highlighted and listed. Finally, moving on to the identification based on types of code-mixing. Before proceeding to the analysis, sample data were selected by using purposive sampling method (Kothari, 2004).

\section{Method and Technique of Analyzing Data}

Qualitative method was used for analyzing data in this study because not any of this analysis is dealing with numbers but rather described in detail. 
Furthermore, qualitative method is used as the analysis method of classifying types of code-mixing and defining factors of using the code-mixing. Technique of analyzing data was done in several steps. First, types of code-mixing sample data that had been chosen, were analyzed and elaborated based on theory of types of code-mixing by Pieter Muysken (2000). Each words being mixed were also categorized in the word class categories based on theory of word class categorization by Robert D. Van Valin Jr. (2001). Second, factors of code-mixing sample data, were elaborated and analyzed based on theory factors of codemixing by Bhatia and Ritchie (2013).

\section{Method and Technique of Presenting Data Analysis}

In this study, formal and informal method are applied for presenting the data analysis. According to Sudaryanto (1993) formal method is a method to presenting data analysis by using number, table, diagram, and symbol while informal method is used to presenting the data analysis by elaborating words and sentences. The first problem uses formal and informal method, the table is used to presenting number of classification types of codemixing and elaboration on the process of code-mixing. The second problem, informal method is applied to explaining the findings and the analysis such as elaborating the analysis types and factors of code-mixing.

\section{FINDINGS AND DISCUSSION}

The analysis of Indonesian - English code-mixing in Touché novel focuses on the utterances produced by the characters. The analysis of types and factors of code-mixing also word class categories of the words being mixed in Touché novel are presented below:

\section{Analysis of the Types of Code-Mixing in Touché Novel}

a. Insertion

Insertion code-mixing occurs if a single constituent of a particular language with the words from the same language is inserted into a structure of other language. A single constituent can be either a lexical item or phrase. The sample data of insertion to be analyzed is written below:

(1) "Permainan yang bagus bukan berasal dari skill." (page 20)

A good performance does not come from skill.

It is the utterance by Mr. Yunus. He is inserting the word "skill" at the end of his utterance. This code-mixing can be categorized as insertion because the speaker inserted a lexical item of English into a structure of Indonesian language which dominate the utterance. The word "skill" is a noun word means someone's ability to do something well. In Indonesian, it means "ketrampilan" or "bakat". The use of the word "skill" is considered more concise and practical than saying "ketrampilan".

\section{b. Alternation}

Alternation code-mixing is when the structure from two languages occur side by side or alternated. It is presented by the clause of two languages. Clause is divided into two independent and dependent clause. Independent clause is the clause that can stand alone as a sentence because it contains a subject, a predicate and a complete thought. Dependent clause is the clause that cannot stand on its own as it is need to be attached to independent clause to form a complete sentence. The dominance between constituent of two languages is undefined. In this perspective, code- 
mixing is similar to intra-sententially code-switching. The utterance written below is the sample data of alternation to be analyzed:

(2) “Your touch absorbs other's mind or feeling, seperti halnya Dani menyerap tulisan." (page 31)

Your touch absorbs other's mind or feeling, just like Dani absorbing writings.

It is uttered by Mr. Yunus. He speaks English at first and mix it with Indonesian at the end. He puts the clause "your touch absorbs other's mind or feeling". This code-mixing can be categorized as alternation. The clause "your touch absorbs other's mind or feeling" is an independent clause because it has complete structure to stand by itself. The structure is subject, predicate, and object. If it is translated into Indonesian, it becomes "sentuhanmu menyerap pikiran atau perasaan orang lain".

\section{c. Congruent Lexicalization}

Congruent lexicalization codemixing is a material from different lexical inventories into a shared grammatical structure or to simplify the definition, it is the mixing of languages that close to each other in structure. According to Muysken, two of features in congruent lexicalization code-mixing are multi-constituent and affix borrowing. The utterance written below is the sample data of congruent lexicalization to be analyzed:

(3) "Is it true atau mereka hanya berusaha menjadi drama queen?" (page 30)

Is it true or they just become a drama queen?
It is uttered by Riska. She begins the sentence with English, continuing with Indonesian and using English at the end. She puts the clause "is it true" and the phrase "drama queen". This code-mixing process can be classified into congruent lexicalization as mentioned in Muysken's theory about multiconstituent congruent lexicalization. The clause "is it true" is a dependent clause because it has incomplete thought to stand by its own. As the characteristic of multi-constituent congruent lexicalization, an English phrase "drama queen" is inserted in the same utterance. "Drama queen" is a noun phrase which the word "queen" performs as the head of phrase. This phrase cannot be interpreted literally, it is a common idiom for a person who shows excessive reactions over small problems. If it is observed from the syntactic structure perspective, the sample data above is a question sentence that offers two choices involving the word "or", also known as an alternative question. The code-mixing process occurs in the first sentence of that question and as the object of the second sentence.

\section{Analysis of Factors of Code-Mixing in Touché Novel}

a. Social roles and relationships of participants

Social roles and relationships of participants is a factor that lead someone to mix codes when there is an unconscious agreement or disagreement on language choice. This means speaker's code-mix depends on who are the participants and the relationship between the speaker and the interlocutor. Some examples from this factor in the novel are as follows:

(4) "Maksud saya, kita sering mendengar atau membaca cerita pewaris 
perusahaan besar mendapat tekanan sejak kecil, nggak happy," (p.30)

(5) "Dengan apa yang kumiliki ini, mana mungkin aku mau menukarnya hanya agar bisa hidup sebagai orang biasa? You must be joking!” (p.30)

All of those data are mixing of languages that taken from one sequence of event, data number (4) is the utterance by Riska and data number (5) is by Mr. Yunus. The author of the novel creates Mr. Yunus' background as someone who is a college graduate from United States of America and describes him as someone who is frequently mixing languages of Indonesian and English in his utterance. While having a conversation with Mr. Yunus who are obviously bilingual, Riska makes an unconscious agreement on her language choice by inserting some English words within the Indonesian sentences. So does Mr. Yunus who is mixing the languages assuming that Riska knows English so well and does not get bothered with codemixing. This novel also shows that someone who is speaking with $\mathrm{Mr}$. Yunus tends to mixing the codes of Indonesian - English more often compared to when speaking to other people. Both, Mr. Yunus and Riska are well aware of who the interlocutor is and they know that the interlocutor understand English. Thus, the data above prove that this factor plays a role in someone's reason to mixing the codes.

\section{b. Situational factors}

According to Bhatia and Ritchie (2013), some languages are viewed as more suited to particular participant/social groups, settings, or topics than others. Situational factor is influencing the speaker to organize two languages according to some factors such as in which setting they are speaking at, the topics, and many other factors for instance gender, religion, class, and age. Therefore, it causes each social group has different languages. Bhatia and Ritchie (2013) also state that organizing different languages in certain situation has some functions as well, for instance creating distance, suppressing tabooness, informality, and intimacy to emotions. An example of occurance from this factor is:

(6) "Di Histoire de Ma Vie versi asli dijelaskan bahwa itulah sebabnya dia bisa menjadi womanizer, penakluk wanita, karena dia bisa membaca pikiran mereka." (p. 38)

The data above can be classified as having an influence from situational factor. It is can be said that the speaker is considering age of the interlocutor, one social variable according to Bhatia and Ritchie (2013). That is the utterance by Mr. Yunus to Dani, Indra and Riska who are much younger. The mixing of English is also used to avoid tabooness of the interaction. Thus the word "womanizer" is used because it is considered more suitable and appropriate.

Another proof that code-mixing is also influenced by social variable such as class is shown in almost all utterances by Mr. Yunus. As previously mentioned that Mr. Yunus is a college graduate from United States of America, he mixes Indonesian and English. Arman who is a professional chef in French tends to mix Indonesian and French. Mixing between languages has been used to show the breadth of their experience and class.

\section{c. Message-intrinsic factor}

What is meant by message-intrinsic is based on linguistics and pragmatics aspects such as quotation, reiteration, message qualification, topiccomment/relative clauses, hedging, interjections, idioms, and deep-rooted 
cultural wisdom. Only five out of seven aspects occur and drive the language mixing in this novel. The example of message-intrinsic factor is discussed below:

(7) "Kau pasti pernah mendengar kalimat ini kan: What is food to one is to others bitter poison." (p. 194)

As shown in the data above, for something that is in form of idiom or related to cultural wisdom is preferably conveyed in the native language. This usually aims to avoid shifting in meaning and misinterpretation.

\section{d. Language attitudes, dominance and security}

The last factor covers individual and social attitudes, language dominance, and linguistic security. For the attitudes, how the speech community views mixing positively or negatively depends on the frequency of bilinguals mix the code and whether it marks particular cultural or social identity or not. Language dominance is influenced by speaker's language proficiency. Last, speaker's security has to do with languages mixing of the bilinguals when they feel insecure (angry, tired, etc.). The example of language dominance factor is:

\section{(8) “Kau punya laptop?” (p. 96)}

The datum above is an utterance by Indra. The word "laptop" occurs several times in the novel. It is an English noun word. In Indonesian, this can be translated into "komputer jinjing". Nevertheless, Indra and the other characters get used to say "laptop" instead. This is a borrowing word from English. Therefore, it has been widely used in daily conversation, rather than the word "komputer jinjing". This proves that when a word from one language is continuously inserted into other language, it is dominated someone's language.

\section{CONCLUSION}

Based on the analysis above, it can be concluded that there are 39 insertion code-mixing, 36 alternation code-mixing, and 10 congruent lexicalization codemixing found in Touché novel. It can be concluded that the most frequently occur is insertion code-mixing and congruent lexicalization code-mixing is the least frequent. In terms of word class categories, from the sample data that had been analyzed, the words being mixed are varied, such as words (i.e. nouns, adjectives, etc.), phrases (i.e. noun phrases, adverb phrases, etc.), and clauses (i.e. dependent and independent clauses).

As for the factor of code-mixing, it is proved that four factors contribute to be the trigger of using code-mixing in the novel. However, only five out of seven aspects in message-intrinsic factors are found. Those are quotation, reiteration, topic-comment/relative clauses, interjections, and idioms and deep-rooted cultural wisdom.

\section{REFERENCES}

Anonim. (2018). Independent and Dependent Clauses. Available from http://www.aims.edu [Accessed on December 2018]

Anonim. (2018). Word Classes and Phrase Classes. Available from https:/dictionary.cambridge.org [Accessed on December 2018]

\footnotetext{
Ansar, Fithrah A. (2017). Code Switching and Code Mixing in TeachingLearning Process. English Education: Jurnal Tadris Bahasa Inggris Vol. 10 (1), 29-45.
} 
Bhatia, T. K., \& Ritchie, W. C. (2013). The Handbook of Bilingualism and Multilingualism 2nd edition. UK: Blackwell Publishing.

Girsang, Mei L. (2015). An Analysis of Code Switching and Code Mixing as Found in Television Advertisement. The Explora Journal of English Language Teaching (ELT) and Linguistics

Holmes, J. (2013). An Introduction to Sociolinguistics. London and New York: Routledge.

Kia, L. S., Cheng, X., Yee, T. K., \& Ling, C. W. (2011). Code-Mixing of English in the Entertainment News of Chinese Newspapers in Malaysia. International Journal of English Linguistics Vol.1 No.1, 314.

Kothari, C. (2004). Research Methodology Methods and Techniques (Second Revised Edition). New Delhi: New Age International (P) Ltd., Publishers.

Mujiono, Wilujeng, R., \& Suharto, M. (2017). Code Mixing as a Communication Strategy Performed by Outbound Call (OBC) Center Agents. International Journal of Social Sciences \& Educational Studies Vol. 3 No. 3, 4-18.

Mulyajati, E. (2017). The IndonesianEnglish Code-Mixing in Just Alvin Show at Metro $T V$. Journal of English Language and Culture Vol. 7 No. 2, 57-63
Muysken, P. (2000). Bilingual Speech: A Typology of Code-Mixing. UK: Cambridge University Press.

Oxford. (2011). Learner's Pocket Dictionary. UK: Oxford University Press.

Sudaryanto. (1993). Metode dan Aneka Teknik Analisis Bahasa (Pengantar Penelitian Wahana Kebudayaan Secara Linguistis). Yogyakarta: Duta Wacana University Press.

Torres, L. (2007). In the Contact Zone: Code-Switching Strategies by Latino/a Writers. MELUS Vol. 32(1), 75-96. Retrieved from http://www.jstor.org/stable/300297 07

Van Valin, J. R. (2001). An Introduction to Syntax. UK: Cambridge University Press.

Wardhaugh, R. (2006). An Introduction to Sociolinguistics 5th Edition. UK: Blackwell Publishing Ltd. 